УДК246.6.001.32(045)

Мельничук М. С.

doi: 10.32620/gch.2018.3.07

\title{
РЕЛІГІЕЗНАВЧО-ФІЛОСОФСЬКА ТРАНСКРИПЦІЯ СИМВОЛУ ТА КАНОНУ В КОНТЕКСТІ РЕЛІГІЙНОГО МИСТЕЦТВА
}

У иій статті автор намагається розкрити особливості впливу таких складових релігійного мистецтва, як символ і канон, у контексті впливу на людину в цілому. Дослідника цікавить прочес функиіонування їх у релігійному мистецтві як з боку релігієзнавчофілософського аналізу, так $і$ з позиції мистецчтвознавства.

Ключові слова: символ, канон, мистецтво, катарсис, культ.

The article makes an attempt to reveal the peculiarities of influence of such components of religious art as symbol and canon in the context of influencing a person as a whole. The researcher is interested in the process of their functioning in religious art both from the religious-philosophical side and from the position of art history.

Keywords: symbol, canon, art, catharsis, cult.

В данной статье автор пытается раскрыть особенности влияния таких составляюших религиозного искусства, как символ и канон, в контексте влияния на человека в иеелом. Автора интересует прочесс функционирования их в религиозном искусстве как со стороны религиоведческо-философского анализа, так и с позищии искусствоведения.

Ключевые слова: символ, канон, искусство, катарсис, культ.

У релігійно-філософському дискурсі як минулого, так і сучасного інтересу релігієзнавчої науки основна увага зосереджена на дослідженні окремих складових мистецького сакрального комплексу.

Серед сучасних українських релігієзнавців цієї проблеми торкалися А. Лещенко (коеволюційні процеси в християнському сакральному мистецтві) та Н. Кравченко (секулярне образотворче мистецтво). Серед радянських дослідників, котрі аналізували відношення релігійної й естетичної складової в житті соціуму, варто згадати С. Булгакова, П. Флоренського, С. Яковлєва, А. Лосєва.

Метою нашої наукової розвідки є спроба аналізу можливої перцепції або ж i результату сприйняття творів релігійно-сакрального мистецтва завдяки символічному й канонічному навантаженню, котрий виражається в посиленні релігійних переживань і зміцненні віри в Бога або ж, як результат, глибокій естетичній насолоді, котра притаманна як глибоко віруючій людині, так і естету атеїсту, i, як наслідок, відчутті катарсису.

Символ як релігійно-художня категорія, безсумнівно, виникає в надрах свідомості ще міфологічної, більш за те - у найперших формах первісного мислення, у якому наявна знакова система, що позначає заступництво й табу. Одностайність між символом i табу особливо чітко виражається в їхній суттєвій рисі: усі вони $\epsilon$ позначенням утаємниченого, незримого смислу, котрий зрозумілий лише посвяченому. 
Іншою суттєвою рисою є те, що вони є знаки того, чим насправді вони не є. У символі ці ознаки найбільш розвинуті й виявлені, тому що символ трансформується в цілу конструкцію, «...яка вказує на щось, чим вона не є» [3, с. 184], і яка несе смисл і ідею, виражаючи їх зовнішньо і внутрішньо [3, с. 196-200]. Так, у християнському Символі віри були сформовані основні принципи вчення про триєдиного Бога: Бога-Отця, БогаСина й Бога-Духа святого. Це вчення було зашифровано в символах-знаках, для позначення яких створені зображальні аналоги: око, ягня й голуб. У подальшому перші два трансформуються, набуваючи антропоморфного характеру, й існують паралельно 3 первісним варіантом.

У християнському богослов'ї є прямі посилання на те, що багато символів християнства запозичено із доби варварства і $\epsilon$ результатом трансформації символів античної релігії, культури й міфології. На це справедливо звертає увагу, зокрема, Л. Успенський: «Символ корабля в далекій давності означав подорож душі в потойбічний світ, а від часу появи християнства став просто символом благополучного житейського шляху, символом благоденства...». А потім корабель став символом Церкви, що «...пливе по хвилях житейського моря, а також символом душі, що ііі веде Церква» [4, с. 53]. Головна ознака символу, отже, полягає в тому, що він догматичний i замкнутий, у його структурі немає вказівки на перспективу, отже, відсутня можливість змін і вдосконалення. М. Еліаде зазначав із цього приводу: «Символи пробуджують особистий досвід і перетворюють його на духовний акт, на метафізичне розуміння Світу. Перед будь-яким деревом, символом Дерева Світу і образом космічного життя, людина до сучасних суспільств могла мати доступ до найвищої духовності: розуміючи символ, вона здатна відчути універсальне» [2, с. 113].

Розуміння прекрасного - процес складний, але визначальну роль тут, зрештою, відіграє соціальна приналежність і світогляд людини. Не випадково релігійний світогляд має значний вплив на сприйняття людиною прекрасного в навколишньому світі. Це можна простежити на сприйнятті одного й того ж явища чи твору мистецтва людьми, що сповідують релігійні або вільнодумні погляди, коли в кожного 3 них виникають цілком відмінні почуття на прикладі «Сікстинської мадонни» Рафаеля. Поет-романтик В. Жуковський, людина глибоко релігійна, трактує цей великий твір мистецтва таким чином: «Богоматір є не що інше, як одушевлений престол Божий, що відчуває велич Того, Хто сидить. I Він, як цар землі й неба, сидить на цьому престолі... Одна рука немовляти з могутністю Вседержителя сперлася на коліно, інша ніби готова піднестися й розпростертися над небом і землею» [5, с. 102]. Зовсім інакше оцінює «Сікстинську мадонну» мистецтвознавець: його захоплює те, що у творі «тема явлення краси сповнена глибокого почуття, вона більш пов'язана із світом людей, зодяглася в плоть і кров, іiі овіяло почуття трагедії всього людського життя. Тема мадонни у Рафаеля злилася з темою звеличення прекрасної жінки... Сила цього образу Рафаеля в тому, що все піднесене стає в нього близьким людям, краса - реальною і земною. Символ жіночої краси зароджувалася у Рафаеля безпосередньо із споглядання світу» $[1$, с. 61$]$.

Попліч із символом у категоріальній структурі релігійно-художнього мислення, на яке спирається, власне, релігійне мистецтво, велике значення має канон. Це історично 
сформована стійка система, яка регулює й організовує духовні конструкції суспільного життя взагалі. У мистецтві й релігії канон виникає на генетичному рівні в процесі ліквідації, розпаду монолітної, універсальної міфологічної свідомості. Тут, у каноні, суспільство прагне на рівнях свідомості, що уже вичленувалися на рівнях форм суспільної свідомості, які формуються чи вже сформувалися, зберегти цілісність i стійкість структури цієї форми свідомості.

Аналізуючи виникнення канону в структурі релігійної й художньої форм суспільної свідомості, дуже складно, а в певних аспектах і неможливо, вичленити суто релігійне чи художнє - так вони історично переплетені. Однак варто зауважити, що істотна відмінність між художнім і релігійним каноном полягає в тому, що коли художній канон є кількісно-структурною моделлю, то релігійний канон є догматом, що пронизує не лише кількісні рівні, але й змістовні, тобто якісні. Тому релігійний канон не допускає відступу не лише від побудови форми, але й від змістовного начала. Так, у християнській агіографічній літературі, у так званих «Житіях святих» існував набір якостей, притаманних святому, тобто була створена певна канонічна схема образу святого. «Життєпис» обов'язково розпочинався 3 незвичного дитинства святого, який уже в той час мав виняткові якості святості: дотримувався постів, був серйозним, не грав 3 іншими дітьми. Ставши дорослим, він обов'язково мав творити чудеса, а наприкінці свого життя прийняти мучеництво [5, с. 107]. Разом із тим канон був тим принципом, який визначав своєрідність побудови архітектурних релігійних споруд $\mathrm{i}$ організацію інших мистецтв навколо цього головного елемента християнського культу. Канони християнського (католицького й православного) архітектурного ансамблю 3 великими площинами нефів i зовнішніх стін храму значною мірою надавали можливість для домінування зображальних елементів у синтезі мистецтв (вітражі, фрески, розпис) [5].

Отже, як символічна, так і канонічна складова релігійного мистецтва не змозі була абсолютно визначати своєрідність художнього мислення. Вони лише в певних історичних межах були здатні на конкретному змістовно-формальному рівні організувати стійкість художньої цілісності. До того ж канон ще більше підкреслював талановитість і оригінальність художника, що творить у його межах, бо щоб створити в межах канону значний художній твір, треба мати неабиякий творчий потенціал, здатність подолати наявні стереотипи. Так, приміром, творчість Андрія Рубльова здійснювалася в межах православно-християнських канонів, але разом із тим вона виходила за його формальні межі, ставши неповторним явищем східнослов'янської культури. Такою ж була і творчість Мікеланджело, Леонардо да Вінчі, Рафаеля й інших геніальних митців західної Церкви, коли вони, створюючи епохальні шедеври мистецтва, усе ж виходили за вузькі межі теологічних приписів. Чим і зумовлено неперевершену досконалість їхньої художньої творчості, як результат колосальної праці та генія дарованого митцю Богом, котра полонить серце як вірянина, так і естета атеїста.

\section{Література:}

1. Алпатов М. В. Всеобщая история искусств. М. ; Л. : Искусство, 1949. Т. 2.410 с. 
2. Еліаде М. Священне і мирське. Міфи, сновидіння і містерії. Мефістофель і андрогін. Окультизм, ворожбитство та культурні уподобання / пер. $з$ нім., фр., англ. Г. Кьорян, В. Сахно. Київ : Вид-во Соломії Павличко «Основи», 2001. 591 с.

3. Лосев А. Ф. Проблема символа и реалистическое искусство. М. : Искусство, 1976. 367 с.

4. Успенский Л. Первохристианское искусство// Журнал Московской Патриархии. 1958. № 8. C. $52-60$.

5. Яковлев Е.Г. Искусство и мировые религии : (система искусств в структуре мировых религий). М. : Высш. шк., 1977. 224 с.

\section{Maksym Melnychuk}

\section{RELIGIOUS-PHILOSOPHICAL TRANSCRIPTION OF SYMBOL AND CANON IN THE CONTEXT OF RELIGIOUS ARTS}

The article makes an attempt to reveal the peculiarities of influence of such components of religious art as symbol and canon, in the context of the impact on man as a whole. The researcher is interested in the process of their functioning in religious art, both from the side of religious-philosophical analysis and from the point of view of art studies.

The symbol, as an integral part of religion, serving both a liturgical and ritualistic function, is the embodiment of the existential meaning of the divine world, immutable and eternal. The symbols clearly demonstrate the presence in the earthly reality of the very beginning of the transcendent, formulating the original position of the connection of the world sinful and sacred. This is their main purpose. Hence, the saturation of religiouscultural symbols with a variety of historical, social, moral-ethical, aesthetic, modern, mystical-esoteric, and other meanings syncretically link in one indissoluble sense, which is involved in the transcendental mystery of being. Hence, the exceptional generalization of religious symbols, due to its abstract nature, maintains its cultural content within the enormous time and space dimensions of epochs, supranational and transgovernmental communities in world religions. Symbolism in religious art allows us to relate the experiences of millions of people to some kind of integrality, different in their ethnic origins and cultural traditions; to act as a form-forming and system-forming factor of separate cultures and whole civilizations.

The Canon as a certain law, which is a typical example for imitation, may be not only religious, but also artistic. The canons of artistic and religious origins are born as an integrity that is difficult to divide, but each of them has its own specifics. The canon is often considered only as a factor limiting the artist, but it also has the other side. Compliance with the canon allowed the artist - even a mediocre one - to reach a high level of artistic creativity. Thus, the average level of mass art production, for example, the ancient Russian icons due to the hard canon is very high. The true artist, working on nuances of artistic form, could show his personality and creative genius.

The symbolic and canonical components of religious art were unable to completely determine peculiarity or uniqueness of artistic thinking. Only in certain historical 
frameworks they were able to organize the stability of artistic integrity at a specific contentformal level. Moreover, the canon emphasized the talent and originality of the artist who created within its framework, as in order to create a significant work of art within the framework of the canon, it is necessary to have a great creative potential, the ability to overcome existing stereotypes. Thus, for example, Andrei Rublev's works were carried out within the limits of the Orthodox, Christian canons, but at the same time it went beyond its formal boundaries, becoming a peculiar and unique phenomenon of the Eastern Slavic culture. The same were the works of other world artists who represented religious and sacred art of the Western Church - each of their geniuses went beyond the narrow limits of theological prescriptions, which is due to the unsurpassed perfection of their artistic creativity, and as a result, the world's artistic heritage.

Keywords: symbol, canon, art, catharsis, cult.

\section{Максим Мельничук}

\section{РЕЛІГІЕЗНАВЧО-ФІЛОСОФСЬКА ТРАНСКРИПЦІЯ СИМВОЛУ ТА КАНОНУ В КОНТЕКСТІ РЕЛІГІЙНОГО МИСТЕЦТВА}

У пропонованій статті автор намагається розкрити особливості впливу таких складових релігійного мистецтва, як символ і канон, у контексті впливу на людину в цілому. Дослідника цікавить процес функціонування їх у релігійному мистецтві як із боку релігієзнавчо-філософського аналізу, так і з позиції мистецтвознавства.

Символ, як невід’ємна складова релігії, виконуючи як літургійну, так ритуалістичну функцію, є уособленням буттєвого смислу божественного світу, незмінного й вічного. Символи демонструють наочно присутність у земній реальності початку саме трансцендентного, формулюють вихідне положення зв'язку світу грішного й сакрального. У цьому полягає їх головне призначення. Звідси насичення релігійно-культурних символів різноманітними історичними, соціальними, моральноетичними, естетичними, сучасними, містико-езотеричними, та іншими смислами, синкретично пов'язаними в один нерозривний зміст, причетний до трансцендентальної таємниці буття. Звідси ж і виняткова узагальненість релігійних символів, що завдяки своїй абстрактності утримують свій культурний зміст у межах величезних за своїм часовим i просторовим масштабом епох, наднаціональних i трансдержавних спільнот у світових релігіях. Символізм у релігійному мистецтві дозволяє зв'язати у якусь цілісність духовні переживання мільйони людей, різних за своїми етнічними витоками й культурними традиціями, постати як формоутворювальний i системоутворювальний чинник окремих культур i цілих цивілізацій.

Канон як певний закон, що є типовим зразком для наслідування, може бути не тільки релігійним, а й художнім. Канон художній і релігійний народжуються як цілісність, яку важко розділити, але є в кожному з них своя специфіка. Часто канон розглядають тільки як обмежувальний для художника фактор, однак у нього є й 
інший бік. Дотримання канону дозволяло художнику навіть посередньому вийти на досить високий рівень художньої творчості. Так, середній рівень масового художнього виробництва, наприклад, давньоруської ікони завдяки жорсткому канону виявляється дуже високим. Справжній митець, працюючи на нюансах художньої форми, міг проявити свою індивідуальність і творчий геній.

Символічна й канонічна складові релігійного мистецтва не в стані були абсолютно визначати своєрідність або й унікальність художнього мислення. Вони лише в певних історичних межах були здатні на конкретному змістовно-формальному рівні організувати стійкість художньої цілісності. До того ж канон ще більше підкреслював талановитість і оригінальність художника, що творить у його межах, бо щоб створити в межах канону значний художній твір, треба мати неабиякий творчий потенціал, здатність подолати наявні стереотипи. Так, приміром, творчість Андрія Рубльова здійснювалася в межах православних, християнських канонів, але разом із тим вона виходила за його формальні межі, ставши неповторним й унікальним явищем східнослов'янської культури. Такою ж була й творчість і інших світових митців, котрі представляли релігійно-сакральне мистецтво західної Церкви: своїм генієм кожен із них виходив за вузькі межі теологічних приписів, чим і зумовлена неперевершена досконалість їхньої художньої творчості і, як результат, довершеність світової мистецької спадщини.

Ключові слова: символ, канон, мистецтвво, катарсис, культ.

Melnychuk Maksym Svyatoslavovich, Candidate of Philosophy, Associate Professor (Docent), National University of Water Management and Nature Management (Rivne, Ukraine) Associate Professor of Department of Philosophy.

Мельничук Максим Святославович - кандидат філософських наук, доцент, доцент кафедри філософії Національного університету водного господарства та природокористування (м. Рівне).

e-mail: m.s.melnuchyk@nuwm.edu.ua

ORCID: 0000-0002-4299-968X

Надійшла до редакції 18.07.2018. Розглянута на редколегії 17.09.2018.

\section{Рецензенти:}

Доктор філософських наук, завідувач кафедри філософії Національного аерокосмічного університету ім. М.Є. Жуковського «ХАI» Чернієнко В.О.

Кандидат філологічних наук, доцент, доцент кафедри документознавства та української мови Національного аерокосмічного університету ім. М.Є. Жуковського «ХАІ» Медведь О.В. 